\title{
地域要因からみる空き家発生リスクの試算に関する研究 \\ 一東京都日野市の空き家調査デー夕を事例に一 \\ LOCAL DIFFERENCES IN PROBABILISTIC RISK ASSESSMENT OF ABANDONED DETACHED HOUSES
}

- Spatial-modeling with Hino city's abandoned housing survey data

西浦 定 継*, 小林利夫**

\section{Sadatsugu NISHIURA and Toshio KOBAYASHI}

\begin{abstract}
This paper focuses on probabilistic risk assessment of detached houses in Hino city of Tokyo, and analyses the probabilities that a detached house would be abandoned with respect to the categorical data of geographical and demographical condition. We use not only statistical survey data but field survey data since we thought that there must be unknown factors influencing the statistically observed data. The analysis shows that areas where are steep slopes and high percentages of the population who are elder that 65 have higher probabilistic risk calculated by generalized liner model with Poisson distribution, applying the integrated nested Laplacian approximation.
\end{abstract}

Keywords : Abandoned house, Geographical condition, Demographical condition, Generalized linear model, Poisson 空き家, 地理的要件, 人口要件, 一般化線形モデル, ポアソン分布

\section{1. はじめに}

本研究では、自治体レベルで実施される空き家調査に含まれる不 確定要因について考察することを目的とする。具体的には、町丁目 単位で、統計資料等から算出される空き家数 (以下、統計空き家数) と、それを受けてさらにアンケート調査、ヒアリング調査などに基 づき特定された空き家数 (以下、調査空き家数) の 2 つの空き家数 を目的変数として、それらと空き家発生に影響すると考えられる地 域特性 (地理的要件、人口要件) との関係性の違いを明らかにする。

日本における空き家数は急増しており、総務省の「H25 年住宅土 地統計調査」によれば全国で約 820 万戸となっている。平成 26 年に は「空き家対策特別措置法」が施行され、所有者不明のまま放置さ れた空き家について行政代執行による対策がとれる道が開かれた。 ただ、除去費用の負担の問題が残っている。一方で、空き家を公営 住宅として活用することも検討されている。耐震性などの基準を満 たす空き家を準公営住宅に指定し、家賃補助と合わせて子育て世代 に提供する仕組みである。このように、空き家対策は喫緊の課題で あり、多くの自治体で条例化されている。一方で、空き家化する前 に対策を講じ、特に放棄されるような事態を避けることも重要な施 策と考える。本論ではこの点に着目し、空き家調查結果における不 確定要因がじこに存在し、どのような対策が求められるかを明らか にし、空き家問題に対する優先的対策の必要性を提示する。

\footnotetext{
* 明星大学理工学部総合理工学科 教授・博士(工学)

** 侏 TPI 都市計画研究所 博士 (工学)
}

\section{2. 分析方法とデータ}

空き家問題に関する研究には、発生要因を明らかにするものと、 発生した空き家の取り扱いを検討するものの 2 つのアプローチがあ る。金森(2015)が述べているように、空き家の増加には土地・住宅 に関する税制、遺産相続における問題、個人の感情など様々な原因 が複雑に絡んでいる。しかし、自治体の人口・世帯構成に着目した 地域特性を考慮することにより、空き家率が増えやすい自治体を明 らかにすることは、空き家に関わる問題への対策の優先度を考える 上でも多くの示唆が得られる。その上で、都道府県レベルでの住宅 ストック量と着工量を利用して住宅の余剩率を計算し、人口及び世 帯構成の地域特性を考慮したモデル分析を行っている。空室率の増 加を止めるには、住宅着工数と減失のバランスを表す余剩着工率を 減じる必要性を論じている。2) 山下 (2015) も宇都宮市を対象として、 市街地の縮退の実態を長期的に把握することを念頭に、縮退パター ンを分析している。宇都宮市水道利用状況データより空き家及び空 き家率のデータベースを作成し、地区ごとに 31 年分の経年変化を 確認し、年代別、地区別に空き家率を算出している。空き家は都市 の中心部や駅周辺、土地区画整理事業が進められている地区で進行 しており、ニュータウン事業や開発事業が行われている地区で、今 後、空き家の増加が著しくなると論じている。3)これらの先行研究 では、都道府県、地方自治体と対象は異なるものの、地域特性を加 味して空き家発生要因を分析し、結論としてきめ細かなデータ分析

Prof., Dept. of Program in Environmental System Engineering, Dept. of Science and Engineering, Meisei University, Dr. Eng.

TPI Town Planning Institute, INC., Dr. Eng. 
に基づく対策の必要性を論じている。

一方で、中西 (2004) は発生した空き家の集約化対策を検討してい る。神奈川県伊勢原市と秦野市を事例として、開発地区内住民に対 し将来の居住に関する意向及び住み替え住宅の有効利用方法に関す る意識調查を実施している。モデルスタディに基づき、住み替えを 契機とした方策の適用可能性を検討している。結論としては、住民 のニーズにうまく対応することで空き家・空き地の解消につながる 可能性があることを示している。4) 三信 (2014) は、発生した空き家 の解体除去の在り方を検討している。広島県呉市を事例として、危 険物除去促進事業の実績の集計、事業認定者に対する空き家の解体 除去事業についてのアンケートを行い、除去事業の改善課題の整理 を行っている。結論として、危険建物除去促進事業の認定者は、60 才以上が 8 割を超えている地区や、斜面住宅地や狭险な道路に接寸 る敷地に建つ空き家を優先的に補助するべき等があげられている。 つまり、認定者の年齢や、地理的要件が空き家除去事業の対象案件 数に大きく影響していることが明らかにされている。5)

本研究で分析対象とするのは、東京都日野市である。人口は約 18 万人、東京都多摩地域に立地し、都心二のアクセスとしては JR 中 央線、京王線があり、さらに多摩都市モノレールが南北に走ってい る。多摩川、浅川の低地部分と多摩丘陵の丘陵地部分が混在する地 形である。人口については、現在において微増が続いている。した がって、上記の先行研究の結果も踏まえて、地理的要因、人口要件 を説明変数として分析する対象とした。

\section{$2-1$. データ}

平成 25 年に日野市が実施した「日野市住宅マスタープラン改訂 調查業務報告書」の中の戸建て住宅の空き家数を用いた注 1 。 報告書 では、以下の理由をあげ、家屋課税台帳のデータだけでは、純粋に 戸建て住宅数が把握できないとしている：(1)戸建て住宅も分譲マン ションも「居住」と表記されている、(2)地番が多数重複している地 番がある、(3)居住と表記されている家屋の中には延床面積が明らか に小さく、倉庫等と思われるものも含まれる。そのため、家屋課税 台帳データ (平成 25 年 1 月時点) と住民基本台帳 (平成 25 年 9 月時 点）の二つのデータを用いて、戸建て空き家を抽出している。具体的 には以下の手順で行っている:(1)家屋課税台帳データにある地番で、 住民基本台帳に記載されていない地番を空き家が存在する所在地と 想定、(2)家屋課税台帳データの特性上注 2)、戸建て住宅数を正確に把 握することは困難であることより、まずは、課税台帳で用途が居宅、 併用住宅、農家住宅の地番を抽出、(3)次に、増改築履歷が新築、地 番が母屋、4 階以上、延べ床面積が $30 \mathrm{~m}^{2}$ 未満、10 件以上重複してい る地番を除外、(4)抽出した地番と住民基本台帳の地番をマッチング させ、マッチングできないものを空き家候補として抽出、(5)さらに、 複数筆に立地する家屋の精査、町名地番の重複が多い家屋の精査、 区画整理地における換地前後の地番の精査を実施、(6)最後に空き家 に関するアンケート調査を行い、抽出案件を再検証する作業を実施 して特定化を図っている。

上記の手続きでも明らかなように、厳密に空き家として特定する ことは難しく、最終的に住民アンケートなどで検証する必要がある。 それでも、不確実性が残ることは明らかである。日野市の場合、家 屋課税台帳データと住民基本台帳のマッチングにより抽出された候 補件数が 3011 件、さらに住民アンケート調查に基づき精查した結
果の件数が 1064 件となっている。実に 3 倍からの開きがある。この 1947 件の差は、空き家発生要因との関連で考えて、どのような特性 を持っているかを検討する。具体的には、目的変数として統計空き 家数 (3011 件) と調查空き家数 (1064 件)、さらにそれらの差である 誤認空き家数 (1947 件) 注3) 用いて空き家発生要因との分析を行う。 本研究で、空き家率ではなくて空き家数を用いたのは、空き家率の 場合、分母と分子の大きさに関連なく同率が発生する可能性があり、 分析結果が意味をなさない事態を避けるためである。

そこで本論では、説明変数としては、三信 (2014) と日野市 (2013) を踏まえて、地理的要件と人口・世帯要件の二つのデータセット (Table1)を用いて行った。地理的要件では地形分類、標高差を用い た。特に標高差は傾斜地住宅に空き家対策の需要が高いという結果 を踏まえたものである。人口要件については、平成 17 年、 22 年の 国勢調查より、町丁目毎の人口・世帯数の増加率、65 才以上の割合 を用いた。65才以上の割合を用いたのは、三信 (2014)でも指摘され ているように、高齢者世帯ほど将来的に空き家になる可能性が高い と判断されるためである。

説明変数のうち、数值データについては、それぞれの平均と標準 偏差で 4 分類してカテゴリーデータとし、各カテゴリーの空き家発 生リスクを算出した。Table 2 の第 2 列目に、平均 $(\mu)$ と標準偏差 （ $\sigma$ )を示した。例えば、elevation (標高差) の場合、 $\mu=29.8 \mathrm{~m} 、 \sigma$ $=20.3 \mathrm{~m}$ を用いて、4 分類にして説明変数としている。4 分類にした 理由としては、一定の幅を持ったカテゴリーデータとすることで、 カテゴリー間の比較による空き家発生リスクを検証するためである。

Table1 The contents of Dataset

\begin{tabular}{|c|c|c|}
\hline & Explanatory Variables & Source \\
\hline \multirow{2}{*}{$\begin{array}{c}\text { Geogra } \\
\text { phical }\end{array}$} & terrain & $\begin{array}{l}\text { Based on Report for Hino City Housing Master } \\
\text { Plan, alluvial lowlands, valley lowlands, hills, and } \\
\text { plateaus are used for categolization. }\end{array}$ \\
\hline & elevation & $\begin{array}{l}\text { The difference between the maximum and the } \\
\text { minimum value within area }\end{array}$ \\
\hline \multirow{4}{*}{$\begin{array}{l}\text { Demog } \\
\text { raphica } \\
\quad 1\end{array}$} & population growth rate & Census data of 2005 and 2010 \\
\hline & household growth rate & Census data of 2005 and 2010 \\
\hline & $\begin{array}{l}\text { Percentage of over } 65 \text { years } \\
\text { old }(2010)\end{array}$ & Census data of 2010 \\
\hline & $\begin{array}{l}\text { Percentage of over } 65 \text { years } \\
\text { old (2005) }\end{array}$ & Census data of 2005 \\
\hline
\end{tabular}

[Statistical data]

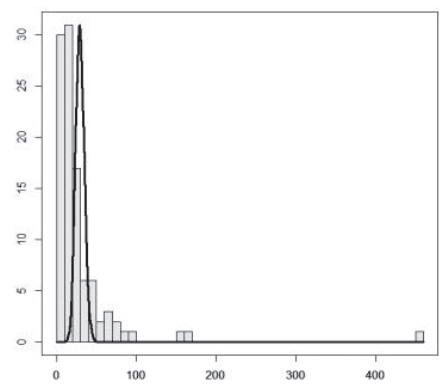

Fig.1 Distribution of Abundant Houses

\section{2-2. 分析方法}

前章で述べたように、目的変数として統計空き家数と調査空き家 数、さらには誤認空き家数を用いる。同じく、先に述べた空き家発 
生要因を説明変数として、一般化線形モデルによるポアソン回帰を 行った。ポアソン回帰を用いるのは、Fig. 1 に示すように、町丁目 単位でみた場合、全戸建て数に対する空き家数の割合は小さく、小 さい事象として発生する確率が高いと判断したためポアソン回帰を 採用した。

一般化線形モデルによるポアソン回帰分析の基本式は以下のとお りである。

$$
\begin{aligned}
& y_{i} \sim \text { Poisson }\left(\lambda_{i}\right) \\
& \log \left(\lambda_{i}\right)=\beta_{0}+\sum_{m=1}^{M} \beta_{m} x_{i m}+\log \left(\text { off set }_{i}\right) \\
& \log \left(\frac{\lambda_{i}}{\text { offset }_{i}}\right)=\beta_{0}+\sum_{m=1}^{M} \beta_{m} x_{i m}
\end{aligned}
$$

$$
\begin{array}{ll}
y_{i}: \text { 目的変数 } & \text { Poisson : ポアソン分布 } \\
\lambda_{\mathrm{i}}: \text { パラメータ } & \beta_{0}: \text { intercept } \\
\beta_{\mathrm{m}} \text { : 回帰係数 } & \mathrm{x}_{\mathrm{im}}: \text { 説明変数 } \\
\text { offset }_{\mathrm{i}} \text { : オフセット設定值 }
\end{array}
$$

式(1)はポアソン分布を設定していること示し、式(2)は線形予測 子と対数リンクを表している。本研究では、目的変数である $3 つ の$ 空き家数に対して、個々の説明変数の単独での影響を見るため、単 回帰の形式をとった。上式で言うと、 $\mathrm{M}=1$ とした。理由は、多変量 でやった場合の変数相互間の影響を避けるためである。式(2)の offset は、回帰係数が常に 1 である説明変数のことである。例えば、 面積当たりの数や単位時間当たりのイベント数などを目的とした分 布において有効とされている。本モデルでも町丁目毎の空き家発生 数を扱うため、オフセット設定值として町丁目毎の全戸建て住宅数 を用いた。

計算は INLA(Integrated Nested Laplace Approximation)理論を 用いて分析を行った。INLA は、ラプラス近似を用いたベイズ統計 解析手法の一つである注 4 )。ラプラス近似は、連続変数の集合上に定 義される確率密度分布に対し、ガウス分布による近似を見出す手法 である。一般的には、モードを見つけて、それを分布の峰と捉えて ガウス分布の近似值を求める。本論でこの手法を用いるのは、式(1) に示寸ように、事後確率分布にポアソン分布を仮定しているので、 パラメータベクトルを積分できないためである。ベイズ統計では、 ある特定のパラメータの事後分布を求める時には、周辺事後確率分 布(joint posterior probability distribution)をラプラス近似で代替 させて計算している。

\section{3. 分析結果}

Table2 に、統計空き家数と調査空き家数の両方を目的変数とした 一般化線形モデルのポアソン回帰の結果を示寸。第 2 章で説明した ように、オフセット值として各町丁目の全戸建て住宅戸数を用いて いる。また、各説明変数は平均と標準偏差を用いてカテゴリーデー 夕に変換している。各回帰係数の事後分布の特性值として、平均、 分散、95\%信頼区間を示しており、対数リンクを取っているため回 帰係数の平均值を戻した值を発生リスクとした。值の解釈としては、 各カテゴリーの第 1 番目が $1(\exp (0)=1)$ となり、第 1 番目に対して どれだけ空き家発生リスク(以下、発生リスク)が高まるか、低まる かを示している。

まず地理的要因についてみてみる。地盤分類についてみると、統
計空き家数は、谷底低地、丘陵、台地と移行寸るに従ってリスクが 低減される点である。これは、地盤がある程度強固になると発生リ スクという点では低くなると言える。一方で、調查空き家数の係数 を見ると、沖積低地よりは、他は寸べて高くなっている。これは、 後述する他の要因(標高差や人口要因)が影響していると考えられる。 次に、町丁目内の標高差についてみてみると、統計空き家数、調査 空き家数ともに標高差が大きいカテゴリーに移行するほど、発生リ スクが高くなる傾向にある。Table2 では、両空き家数とも、第 3 、 第 4 カテゴリー(factor3, factor4)の方が第 2 カテゴリー(factor2)よ りも発生リスク (Risk) が高く表れている。町丁目内で傾斜がきつい ところでは、2 倍近くリスクが高まる。調査空き家数に比べて、統 計空き家数の值が高く出ているのは、統計資料などだけでは把握で きない誤認空き家数が多く含まれていることによると考えられる。

次に人口・世帯数要件をみてみる。人口増加率についてみると、 統計空き家数、調查空き家数ともに、人口増加率の高いカテゴリー で発生リスクが高まっている。統計空き家数では第 3 カテゴリー (2. 014)、調査空き家数でも第 2 カテゴリー(1.426) となっている。 第 1 カテゴリーに比べて、それぞれ 2.014 倍、1.426 倍の発生リス ク上昇がみられる。普通に考えれば、人口増加率が低い第 1 カテゴ リーで発生リスクが高いと考えられるが、山下 (2015) でも論じられ ているように既存物件と新築物件が混在するところで空き家になっ ていくリスクがあると考えられる。世帯数増加率でみると、統計空 き家数では人口増加率と同じく第 3 カテゴリー (1.543)で高くなっ ている。これは、誤認空き家数の影響が考えられる。一方で、調査 空き家数では、世帯数増加率の最も低い第 1 カテゴリーが最も発生 リスクが高く表れている。これをみると、世帯数増加率については、 増加率の低いところに空き家発生リスクがあることがうかがえる。

次に、65才以上の人口割合でみてみる。統計空き家数では、平成 22 年、平成 17 年ともに第 2 カテゴリーが最も高く、第 $3 、$ 第 4 と移 行するにしたがって、低くなっている。一方、調查空き家数では、 第 2、第 3、第 4 と人口割合が高くなっていくほど、発生リスクが高 くなっている。常識的に考えると、65才から 70 才以上の年噛階層 の割合が高い地区で発生リスクが高くなることが考えられ、これを 踏まえると、調査空き家数の結果は妥当と判断できる。一方、統計 空き家数の結果については、多分に第 3 及び第 4 カテゴリーに誤認 空き家が含まれていることが要因と考えられる。

上記の解析結果において、空き家発生リスクに大きな影響を与え ているであろう、標高差、6 5 才以上の割合 (平成 22 年と平成 17 年) と調查空き家数の空間分布を Fig. 2 に示す。調查空き家数の分布図 [Spatial Distributions of Surveyed Data]、標高差の分布図 [Elevation]、2010 年時点の 65 才以上の人口割合分布図 [Over 65 years old (2010) ] を比べると、調査空き家数が多い地区、標高差の 高い地区、65才以上の割合が高い地区が重なっている(黒塗りの地 区) ことがわかる。2005 年で 65 才以上の人口割合分布図 [Over 65 years old (2005) ] でも第 3 カテゴリーの地区が上記の黒塗りの地 区と多くが重祆っている。つまり、空き家数の多いところは、標高 差が大きく、65 才以上の割合が高いところとなっていることが確認 
Table2 Simulated Outcomes by Poisson Regression Analysis for Statistical and Surveyed Data

\begin{tabular}{|c|c|c|c|c|c|c|c|c|c|c|c|c|}
\hline \multirow{3}{*}{\begin{tabular}{|c|} 
Explan \\
atory \\
Variabl \\
es \\
\end{tabular}} & \multirow[b]{3}{*}{ Group } & \multirow[b]{3}{*}{ Category } & \multirow{2}{*}{\multicolumn{5}{|c|}{\begin{tabular}{l|l}
\multicolumn{2}{c}{ Objective variable : statistical data (abandoned house) } \\
Risk & Posterior distribution of regression coefficient
\end{tabular}}} & \multicolumn{5}{|c|}{ Objective variable : surveyed data (abandoned house) } \\
\hline & & & & & & & & \multirow{2}{*}{$\begin{array}{l}\text { 発生リスク } \\
(\operatorname{EXP}(\beta \mathrm{m}))\end{array}$} & \multicolumn{4}{|c|}{ Posterior distribution of regression coefficient } \\
\hline & & & $\begin{array}{c}\text { Risk } \\
(\operatorname{EXP}(\beta \mathrm{m}))\end{array}$ & \multicolumn{2}{|c|}{\begin{tabular}{l|l} 
Mean & Variance \\
$(\beta m)$ &
\end{tabular}} & \multicolumn{2}{|c|}{$95 \%$ confidence interval } & & $\begin{array}{l}\text { Mean } \\
(\beta m)\end{array}$ & Variance & $95 \%$ confide & interval \\
\hline \multirow{10}{*}{\begin{tabular}{|} 
Geogr \\
aphical
\end{tabular}} & \multirow{5}{*}{ terrain } & (Intercept) & 0.140 & -1.967 & 0.031 & -2.028 & -1.906 & 0.024 & -3.717 & 0.074 & -3.866 & -3.574 \\
\hline & & $\begin{array}{l}\begin{array}{l}\text { factor1(alluvial lowlands } \\
\text { 沖積低地) }\end{array} \\
\end{array}$ & 1.000 & 0.000 & & & & 1.000 & 0.000 & & & \\
\hline & & $\begin{array}{l}\text { factor2 (valley lowlands } \\
\text { 谷底低地) }\end{array}$ & 0.939 & -0.064 & 0.062 & -0.186 & 0.056 & 1.843 & 0.605 & 0.118 & 0.372 & 0.834 \\
\hline & & factor3(hills 丘陵) & 0.561 & -0.579 & 0.051 & -0.678 & -0.480 & 1.645 & 0.493 & 0.093 & 0.312 & 0.677 \\
\hline & & factor4(plateaus 台地) & 0.557 & -0.586 & 0.045 & -0.673 & -0.498 & 1.439 & 0.360 & 0.089 & 0.188 & 0.535 \\
\hline & \multirow{5}{*}{$\begin{array}{l}\text { elevation } \\
\mu=28.8 \mathrm{~m} \\
\sigma=20.3 \mathrm{~m}\end{array}$} & (Intercept) & 0.046 & -3.099 & 0.147 & -3.400 & -2.821 & 0.022 & -3.836 & 0.213 & -4.279 & -3.441 \\
\hline & & factor $1(\mu-2 \sigma)$ & 1.000 & 0.000 & & & & 1.000 & 0.000 & & & \\
\hline & & factor2 $(\mu-\sigma)$ & 2.048 & 0.706 & 0.149 & 0.423 & 1.011 & 1.524 & 0.397 & 0.217 & -0.008 & 0.847 \\
\hline & & factor $3(\mu+\sigma)$ & 2.851 & 1.036 & 0.152 & 0.749 & 1.345 & 1.696 & 0.503 & 0.223 & 0.085 & 0.963 \\
\hline & & factor4 $(\mu+2 \sigma)$ & 2.124 & 0.741 & 0.154 & 0.449 & 1.055 & 2.056 & 0.696 & 0.223 & 0.278 & 1.156 \\
\hline \multirow{20}{*}{$\mid \begin{array}{c}\text { Demog } \\
\text { raphic } \\
\text { al }\end{array}$} & \multirow{5}{*}{$\begin{array}{c}\text { population growth } \\
\text { rate } \\
\text { (2005 to } 2010 \text { ) } \\
\mu=4.3 \% \\
\sigma=16.8 \% \\
\end{array}$} & (Intercept) & 0.069 & -2.676 & 0.121 & -2.922 & -2.445 & 0.025 & -3.677 & 0.200 & -4.091 & -3.304 \\
\hline & & factor1 $(\mu-2 \sigma)$ & 1.000 & 0.000 & & & & 1.000 & 0.000 & & & \\
\hline & & factor2 $(\mu-\sigma)$ & 1.228 & 0.205 & 0.124 & -0.030 & 0.456 & $\begin{array}{l}1.426 \\
\end{array}$ & 0.355 & 0.203 & -0.026 & 0.775 \\
\hline & & factor $3(\mu+\sigma)$ & 2.014 & 0.700 & 0.125 & 0.462 & 0.953 & 1.310 & 0.270 & 0.209 & -0.122 & 0.700 \\
\hline & & factor4 $(\mu+2 \sigma)$ & 1.026 & 0.025 & 0.154 & -0.274 & 0.331 & 1.015 & 0.015 & 0.255 & -0.478 & 0.523 \\
\hline & \multirow{5}{*}{$\begin{array}{c}\text { household growth } \\
\text { rare } \\
(2005 \text { to } 2010) \\
\mu=3.1 \% \\
\sigma=13.3 \%\end{array}$} & (Intercept) & 0.081 & -2.518 & 0.043 & -2.603 & -2.436 & 0.039 & -3.239 & 0.061 & -3.361 & -3.121 \\
\hline & & factor $1(\mu-2 \sigma)$ & 1.000 & 0.000 & & & & 1.000 & 0.000 & & & \\
\hline & & factor2 $2(\mu-\sigma)$ & 1.020 & 0.020 & 0.056 & -0.089 & 0.130 & $\begin{array}{l}0.796 \\
\end{array}$ & -0.229 & 0.085 & -0.394 & -0.062 \\
\hline & & factor $3(\mu+\sigma)$ & 1.543 & 0.434 & 0.050 & 0.337 & 0.532 & 0.896 & -0.110 & 0.078 & -0.262 & 0.043 \\
\hline & & factor4 $(\mu+2 \sigma)$ & 0.864 & -0.146 & 0.092 & -0.330 & 0.033 & 0.739 & -0.302 & 0.141 & -0.585 & -0.032 \\
\hline & \multirow{5}{*}{\begin{tabular}{|c} 
percentage of \\
over 65 years old \\
$(2010)$ \\
$\mu=20.6 \%$ \\
$\sigma=7.8 \%$ \\
\end{tabular}} & (Intercept) & 0.062 & -2.775 & 0.075 & -2.924 & -2.631 & 0.025 & -3.691 & 0.118 & -3.930 & -3.467 \\
\hline & & factor $1(\mu-2 \sigma)$ & 1.000 & 0.000 & & & & 1.000 & 0.000 & & & \\
\hline & & factor2 $(\mu-\sigma)$ & 1.817 & 0.597 & 0.079 & 0.444 & 0.756 & $\begin{array}{ll}1.236 \\
\end{array}$ & 0.212 & 0.129 & $\begin{array}{l}-0.036 \\
\end{array}$ & 0.471 \\
\hline & & factor $3(\mu+\sigma)$ & 1.535 & 0.429 & 0.080 & 0.273 & 0.589 & 1.497 & 0.403 & 0.127 & 0.160 & 0.659 \\
\hline & & factor $4(\mu+2 \sigma)$ & 1.370 & 0.315 & 0.091 & 0.138 & 0.495 & $\begin{array}{ll}1.703 \\
\end{array}$ & 0.533 & 0.139 & 0.264 & 0.810 \\
\hline & \multirow{5}{*}{$\begin{array}{c}\text { percentage of } \\
\text { over } 65 \text { years old } \\
(2005) \\
\mu=17.2 \% \\
\sigma=7.0 \%\end{array}$} & (Intercept) & 0.057 & -2.858 & 0.089 & -3.037 & -2.687 & 0.025 & -3.687 & 0.135 & -3.961 & -3.432 \\
\hline & & factor $1(\mu-2 \sigma)$ & 1.000 & 0.000 & & & & 1.000 & 0.000 & & & \\
\hline & & factor $2(\mu-\sigma)$ & 1.992 & 0.689 & 0.093 & 0.511 & 0.876 & $\begin{array}{ll}1.192 \\
\end{array}$ & 0.176 & 0.144 & -0.100 & 0.468 \\
\hline & & factor $3(\mu+\sigma)$ & 1.488 & 0.397 & 0.096 & 0.212 & 0.590 & 1.421 & 0.351 & 0.146 & 0.073 & 0.647 \\
\hline & & factor $4(\mu+2 \sigma)$ & 1.693 & 0.527 & 0.097 & 0.339 & 0.721 & \begin{tabular}{l|l}
1.762 \\
\end{tabular} & 0.567 & 0.147 & 0.287 & 0.863 \\
\hline
\end{tabular}

できる。

更に、Table3 に誤認空き家数を目的変数とし て計算した結果を示す。この表は、どのカテゴ リーで誤認空き家数の発生するリスクがある かを示している。言い換えれば、空き家と判断 するために、特にアンケート、ヒアリングなど のきめ細かな調查をする必要のあるカテゴリ 一を示している。標高差では第 3 カテゴリー (3.888)、人口増加率でも第 3 カテゴリー (2.423)、世帯数増加率でも第 3 カテゴリー (2.157)、65 才以上の割合平成 22 年では第 2 カ テゴリー (2.205)、平成 17 年でも第 2 カテゴリ 一(2.613) となっている。それぞれ、カテゴリー 分けで言うと、中位レベルにおいて統計資料等 の調査だけからは確認できない空き家が多く 含まれている。つまり、このレベルに分類され る町丁目については、綿密な調査が必要という ことである。

\section{4. まとめ}

本論の分析から以下のような知見が得られ た。

(1) 統計資料等から算出される空き家数 (統計 空き家数) と、さらにアンケート調查、ヒア
Table3 Simulated Outcomes by Poisson Regression Analysis for Miscounted Data

\begin{tabular}{|c|c|c|c|c|c|c|c|}
\hline \multirow{3}{*}{\begin{tabular}{|c} 
Explan \\
atory \\
Variabl \\
es
\end{tabular}} & \multirow{3}{*}{ Group } & \multirow{3}{*}{ Category } & \multicolumn{5}{|c|}{ Objective variable : miscounted data (abandoned house) } \\
\hline & & & \multirow{2}{*}{$\begin{array}{c}\text { Risk } \\
(\operatorname{EXP}(\beta \mathrm{m}))\end{array}$} & \multicolumn{4}{|c|}{ Posterior distribution of regression coefficient } \\
\hline & & & & Mean & Variance & $95 \%$ confide & interval \\
\hline \multirow{10}{*}{$\begin{array}{c}\text { Geogr } \\
\text { aphical }\end{array}$} & \multirow{5}{*}{ terrain } & (Intercept) & 0.116 & -2.157 & 0.034 & -2.225 & -2.091 \\
\hline & & $\begin{array}{l}\text { factor1(alluvial lowlands } \\
\text { 沖積低地) }\end{array}$ & 1.000 & 0.000 & & & \\
\hline & & $\begin{array}{l}\text { factor2 (valley lowlands } \\
\text { 谷底低地) }\end{array}$ & 0.750 & -0.288 & 0.074 & -0.434 & -0.145 \\
\hline & & factor3(hills 丘陵) & 0.334 & -1.096 & 0.067 & -1.227 & -0.966 \\
\hline & & factor4(plateaus 台地) & 0.373 & -0.987 & 0.055 & -1.096 & -0.880 \\
\hline & \multirow{5}{*}{$\begin{array}{l}\text { elevation } \\
\mu=28.8 \mathrm{~m} \\
\sigma=20.3 \mathrm{~m}\end{array}$} & (Intercept) & 0.024 & -3.749 & 0.204 & -4.172 & -3.370 \\
\hline & & factor $1(\mu-2 \sigma)$ & 1.000 & 0.000 & & & \\
\hline & & factor2 $(\mu-\sigma)$ & 2.517 & 0.923 & 0.206 & 0.538 & 1.350 \\
\hline & & factor $3(\mu+\sigma)$ & 3.888 & 1.358 & 0.208 & 0.969 & 1.788 \\
\hline & & factor $4(\mu+2 \sigma)$ & 2.184 & 0.781 & 0.213 & 0.382 & 1.220 \\
\hline \multirow{20}{*}{$\begin{array}{c}\text { Demog } \\
\text { raphic } \\
\text { al }\end{array}$} & \multirow{5}{*}{$\begin{array}{c}\text { population growth } \\
\text { rate } \\
\begin{array}{c}2005 \text { to } 2010) \\
\mu=4.3 \% \\
\sigma=16.8 \%\end{array}\end{array}$} & (Intercept) & 0.044 & -3.134 & 0.153 & -3.446 & -2.847 \\
\hline & & factor $1(\mu-2 \sigma)$ & 1.000 & 0.000 & & & \\
\hline & & factor2 $(\mu-\sigma)$ & 1.113 & 0.107 & 0.156 & -0.188 & 0.426 \\
\hline & & factor $3(\mu+\sigma)$ & 2.423 & 0.885 & 0.156 & 0.590 & 1.204 \\
\hline & & factor $4(\mu+2 \sigma)$ & 1.032 & 0.032 & 0.194 & -0.344 & 0.417 \\
\hline & \multirow{5}{*}{$\begin{array}{c}\text { household growth } \\
\text { rare } \\
\text { (2005 to } 2010 \text { ) } \\
\mu=3.1 \% \\
\sigma=13.3 \% \\
\end{array}$} & (Intercept) & 0.041 & -3.185 & 0.059 & -3.303 & -3.070 \\
\hline & & factor $1(\mu-2 \sigma)$ & 1.000 & 0.000 & & & \\
\hline & & factor2 $(\mu-\sigma)$ & 1.233 & 0.209 & 0.075 & 0.063 & 0.357 \\
\hline & & factor $3(\mu+\sigma)$ & 2.157 & 0.769 & 0.067 & 0.640 & 0.901 \\
\hline & & factor $4(\mu+2 \sigma)$ & 0.983 & -0.018 & 0.123 & -0.263 & 0.219 \\
\hline & \multirow{5}{*}{$\begin{array}{c}\text { percentage of } \\
\text { over } 65 \text { years old } \\
(2010) \\
\mu=20.6 \% \\
\sigma=7.8 \% \\
\end{array}$} & (Intercept) & 0.037 & -3.285 & 0.096 & -3.479 & -3.101 \\
\hline & & factor $1(\mu-2 \sigma)$ & 1.000 & 0.000 & & & \\
\hline & & factor2 $(\mu-\sigma)$ & 2.205 & 0.791 & 0.101 & 0.596 & 0.995 \\
\hline & & factor $3(\mu+\sigma)$ & 1.561 & 0.445 & 0.104 & 0.246 & 0.653 \\
\hline & & factor $4(\mu+2 \sigma)$ & 1.148 & 0.138 & 0.121 & -0.098 & 0.378 \\
\hline & \multirow{5}{*}{\begin{tabular}{|c|} 
percentage of \\
over 65 years old \\
$(2005)$ \\
$\mu=17.2 \%$ \\
$\sigma=7.0 \%$
\end{tabular}} & (Intercept) & 0.032 & -3.432 & 0.119 & -3.672 & -3.206 \\
\hline & & factor $1(\mu-2 \sigma)$ & 1.000 & 0.000 & & & \\
\hline & & factor2 $(\mu-\sigma)$ & 2.613 & 0.960 & 0.123 & 0.727 & 1.209 \\
\hline & & factor $3(\mu+\sigma)$ & 1.539 & 0.431 & 0.128 & 0.187 & 0.689 \\
\hline & & factor $4(\mu+2 \sigma)$ & 1.639 & 0.494 & 0.130 & 0.246 & 0.755 \\
\hline
\end{tabular}



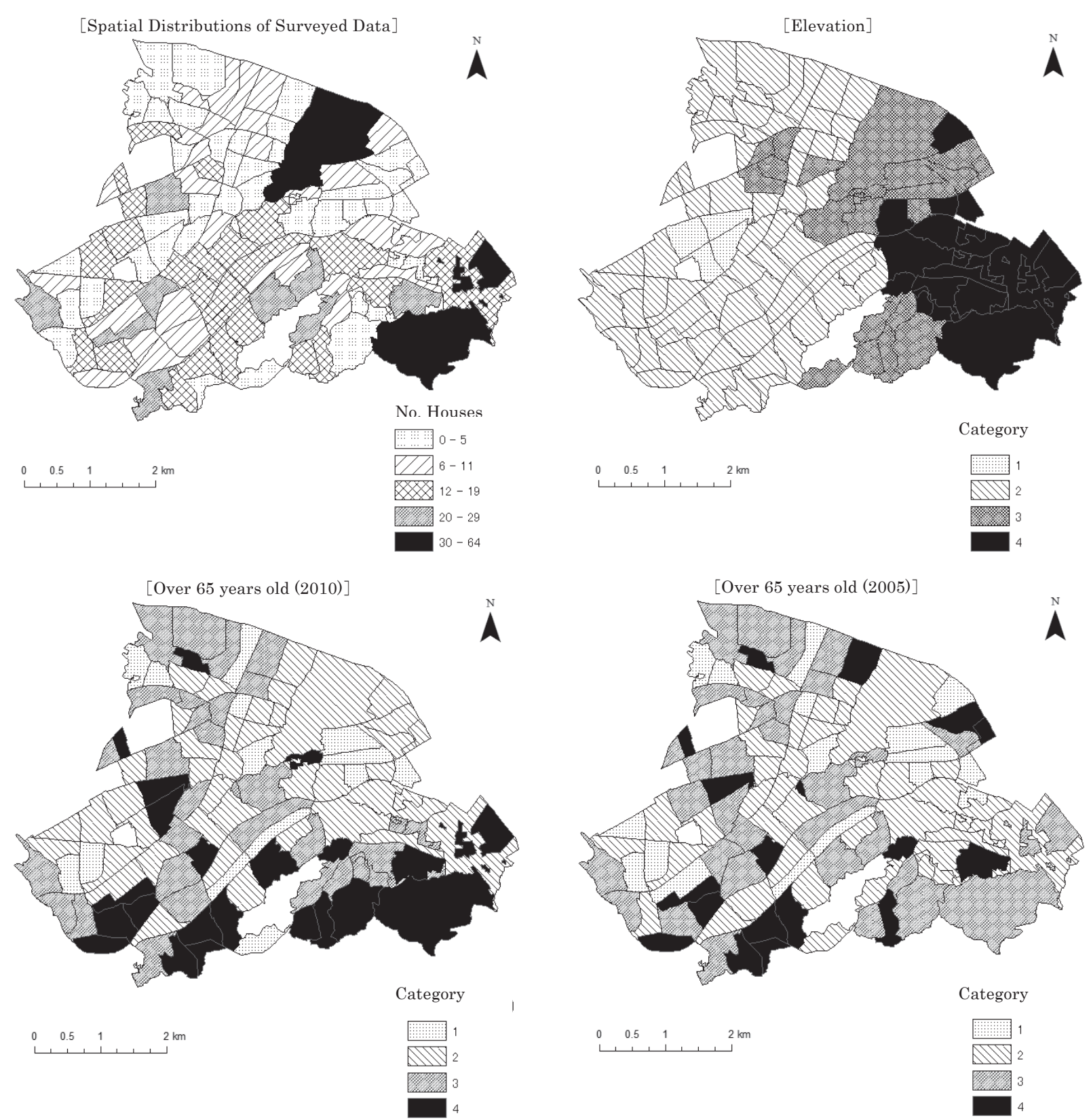

Fig.2 Spatial Distributions of Surveyed Data, Elevation, Percentage of Over 65 years old $(2010,2005)$

リング調査に基づいて特定された空き家数 (調査空き家数) とを 用いて、一般化線形モデルのポアソン回帰分析を行ったところ、 誤認空き家数の影響が部分的に表れていることが確認できた。

(2) 統計空き家数、調査空き家数ともに、標高差が大きいカテゴリ 一に移行するほど、発生リスクが高くなる傾向にある。町丁目 内で傾斜がきついところでは、2 倍近くリスクが高まる。

(3) 人口増加率では、第 2、第 3 カテゴリーの発生リスクが高く表 れ、既存物件と新築物件が混在するところで空き家になってい くリスクがある。

(4) 65 才以上の割合からは、65才から 70 才以上の年齢階層の割合 が高い地区で発生リスクが高く表れる。

高齢化、人口減少に伴い、全国で空き家対策が検討、実施されて
きている。本論の分析結果を踏まえた場合、空き家問題に対する優 先的対策と求められる対応としては、まずは、標高差が大きく、65 才以上の人口割合が高い地区を特定することである。地理的要因、 人口要因は確定的であり、将来的に必ず空き家発生に大きく影響し てくる。従って、それら要因に合致する地区を細かく調查、観測、 特定し、空き家化する前に所有者とコンタクトを取り、意向を把握 する必要がある。所有のまま行政に管理を委福るのか、所有権を手 放すのかに関する意向を把握し、事前に地域金融機関や不動産関係 者等と連携しながら有効活用対策を講じることが求められる。所有 者不明のまま空き家化した場合、その対策にかかる社会的コストは 非常に大きくなる。

本論で用いた一般化線形モデルのポアソン回帰分析では、分析対 象である日野市の立地条件、既往研究の結果を踏まえて地理的要件 
と人口要件を発生リスク要因として選定した。当然ながら、これは どこの都市でも当てはまるわけではなく、立地条件によって選定さ れる要因も変わってくるであろう。しかし、分析手法については適 用可能であり、リスクを踏まえた政策立案が求められる。

今後は、本論では対象外とした集合住宅の空き家、空き部屋対策 も喫緊の課題であり、今後の研究課題としたい。

\section{参考文献}

1) The city of Hino : Report for Hino City Housing Master Plan, The city of Hino, 2014

日野市：日野市住宅マスタープラン改訂調査業務 報告書, 日野市, 2014

2) Kanamori, Yuko. Ariga, T. and Matsuhasi, K. : Factor analysis and estimation of rate of vacant dwellings The City Planning Institute of Japan, Vol 50 No. 3, pp. 1017-1024, 2015. 10 金森有子 他: 空き家率の要因分析と将来推計, 都市計画論文集 Vol 50 No. 3, pp. 1017-1024, 2015. 10

3) Yamashita, S. and Morimoto, A. : Study on Occurrence Pattern of the Vacant Houses in the Local Hub City, The City Planning Institute of Japan, Vol 50 No. 3, pp. 932-937, 2015. 10

山下伸 他：地方中核都市における空き家の発生パターンに関する研究, 都市計画論文集 Vol 50 No. 3, pp. 932-937，2015. 10

4) Nakanishi, M., Suzuki, A., and Nakai, N. : A Study of dissolution of vacant land and the intention of residents in the suburban housing developments, The City Planning Institute of Japan, No. 39-3, pp. 631636, 2004. 11

中西正彦 他: 首都圈郊外の住宅開発における空き地・空き家の解消方策 に関する研究, 都市計画論文集 No. 39-3, pp. 631-636, 2004. 11

5) San-nobu, A. and Sshinobe, H : A study on the demolition clearance policy of vacant house, The City Planning Institute of Japan, Vol 49 No. 3, pp. 357-362, 2014. 10

三信篤志 他： 空き家の解体除却整備に関寸る研究 - 吳市危険建物除却 促進事業を事例として一，都市計画論文集 Vol 49 No. 3，pp．357-362， 2014. 10

6) Kasuya, A. : Generalized Linear Models, Kyoritsu, 2014 粕谷栄一：Ｒ で学ぶデータサイエンス一般化線形モデル，共立出版， 2012

7) Kyo, K. : Bayesian Statistical Methods for Data Analysis, Kyoritsu, 2010

姜 興起：R で学ぶデータサイエンス ベイズ統計データ解析，共立出版， 2010

8) Ando, T. : Bayesian Statistical Modeling, Asakura, 2010 安道知寛: ベイズ統計モデリング, 朝倉書店, 2010

9) Albert, Jim, Bayesian Computation with R, NJ : Springer, 2009

10) Gelman, Andrew, others, Bayesian Data Analysis, FL : Chapman \& Hall/CRC, 2004

11) Blangiardo, M, Cameletti, M. : Spatial and Spatio-temporal Bayesian models with R-INLA, UK: Wiley, 2015

12) Bishop, Christopher, Pattern Recognition and Machine Learning, U.K.: Springer

注

注 1) 平成 26 年 3 月の報告書として取りまとめられている。その中で、空き 家調査として、戸建て住宅、賃貸共同住宅のそれぞれの空き家数を調査 している。加えて、人口、世帯、地理的要因、開発許可、面的整備要件な ども加えてまとめており、行政資料として信頼できるデータと判断し、 本研究に活用した。

注 2) 家屋課税台帳データでは、戸建て住宅及び分譲マンションも同じ用途区 分「居宅」となっており、加えて居宅区分にも倉庫等と推定される微小 の床面積も存在している。

注 3)ここで「誤認」という表現を使ったのは、仮に統計資料だけで空き家と 判断した場合、䛊った判断になるためである。
注 4) 以下に、INLA 理論の計算の流れを示す。

$\int f(x) d x=\int \exp (\log f(x)) d x$

$$
f(x) \text { : 確率密度関数 }
$$

上式の $\log f(x)$ についてテーラー展開を適用すると

$\log f(x) \approx \log f\left(x_{0}\right)+\left.\left(x-x_{0}\right) \frac{\partial \log f(x)}{\partial x}\right|_{x=x_{0}}$

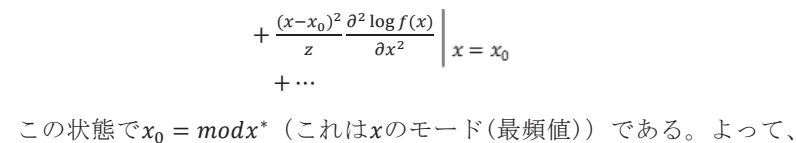

$\frac{\partial \log f(x)}{\partial x}=0$

式は以下のような近似となる。

$\log f(x) \approx \log f\left(x^{*}\right)+\frac{\left(x-x^{*}\right)}{z} \frac{\partial^{2} \log f(x)}{\partial x^{2}}$

上式を最初の式にあてはめて計算することになる。 


\section{LOCAL DIFFERENCES IN PROBABILISTIC RISK ASSESSMENT \\ OF ABANDONED DETACHED HOUSES}

- Spatial-modeling with Hino city's abandoned housing survey data

\section{Sadatsugu NISHIURA* and Toshio KOBAYASHI**}

\footnotetext{
* Prof., Dept. of Program in Environmental System Engineering, Dept. of Science and Engineering, Meisei University, Dr. Eng.
} ** TPI Town Planning Institute, INC., Dr. Eng.

This paper focuses on probabilistic risk assessment of detached houses in Hino city of Tokyo, and analyses the probabilities that a detached house would be abandoned with respect to the categorical data of geographical and demographical condition. Hino city has been developed along Tamagawa and Asakawa rivers and on Tama hills. Therefore, it is appropriate area for our research focusing on how geographical and demographical condition would influence on the risk of occurrence of abandoned house. We use not only statistical survey data but field survey data, which revealed incorrectly counted houses as abandoned, since we thought that there must be unknown factors influencing the statistically observed data.

From the analysis of this paper, we found that: 1) it was confirmed that the influence of the number of miscounted data in statistically collected data by applying Poisson regression analysis of the generalized linear model with integrated nested Laplacian approximation (INLA) using the number of abandoned houses (statistical number) and the questionnaire survey data, 2) the risk of occurrence tends to increase in the categories where the altitude difference is large. Its risk increases by nearly twice, 3) in the population categories, the risk of occurrence of the second and third categories appears high, there is a risk of becoming abandoned house where existing property and newly built property mix, 4) from the ratio of 65 years old or over, the risk of occurrence appears high in the district where the percentage of age group from 65 years old to 70 years old is high.

With the aging of the population and the declining population, abandoned house countermeasures have been studied and implemented nationwide. As administrative response, we are struggling with how to treat the house itself, upon request of the residents. One effective means, however, is to take measures before becoming an abandoned. For that purpose, we propose to collect more detailed and individually surveyed data.

In the Poisson regression analysis of the generalized linear model used in this paper, geographical and population requirements were selected as occurrence risk factors based on the location condition of Hino City, which is the analysis target, and the results of the past research. Of course, this is not the case in any city, and the factors selected depending on the location will change. However, analytical methods can be applied, and policy making based on risks is required. In the future, abandoned houses and unoccupied rooms countermeasures for apartment houses that were not covered in this paper are also urgent issues and I would like to make them future research subjects. 